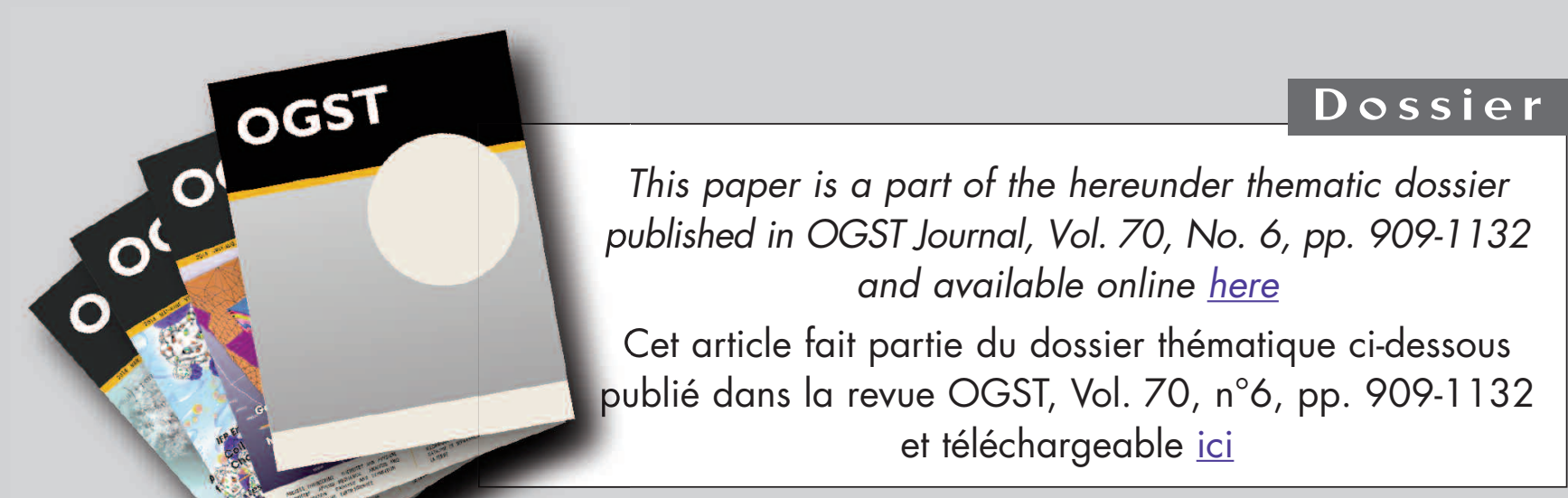

Oil \& Gas Science and Technology - Rev. IFP Energies nouvelles, Vol. 70 (2015), No. 6, pp. 909-1132

Copyright (C) 2015, IFP Energies nouvelles

909 > Editorial - Enhanced Oil Recovery (EOR), Asphaltenes and Hydrates Éditorial - EOR «récupération assistée du pétrole», Asphaltènes et Hydrates D. Langevin and F. Baudin

\section{ENHANCED OIL RECOVERY (EOR)}

917 > HP-HT Drilling Mud Based on Environmently-Friendly Fluorinated Chemicals Boues de forage HP/HT à base de composés fluorés respectueux de I'environnement

I. Henaut, D. Pasquier, S. Rovinetti and B. Espagne

931 > Effective Viscosity in Porous Media and Applicable Limitations for Polymer Flooding of an Associative Polymer

Viscosité effective dans des médias poreux et limites d'application de l'injection de polymères associatifs

P. Zhang, Y. Wang, Y. Yang, W. Chen and S. Bai

$941>$ Dynamic Gelation of HPAM/Cr(III) under Shear in an Agitator and Porous Media Gélification dynamique de HPAM/Cr(III) sous cisaillement dans un agitateur et en milieu poreux

Y. Haiyang, W. Yefei, Z. Jian, L. Peng and S. Shenglong

$951>$ Computer Modeling of the Displacement Behavior of Carbon Dioxide in Undersaturated Oil Reservoirs

Modélisation par ordinateur du comportement de déplacement du dioxyde de carbone dans des réservoirs d'huile non saturés

B. Ju, Y.S. Wu and J. Qin

$967>$ Predicting CO, Minimum Miscibility Pressure (MMP) Using Alternating Conditional Expectation (ACE) Algorithm

Prédiction de la pression miscibilité minimum (MMP) du CO en utilisant un algorithme basé sur l'ACE (Alternating Conditional Expectation)

0 . Alomair, A. Malallah, A. Elsharkawy and M. Iqbal

983 > Towards the Development of Bitumen Carbonates: An Integrated Analysis of Grosmont Steam Pilots

Vers le développement des carbonates bitumineux : une analyse intégrée des pilotes vapeur de Grosmont

C.C. Ezeuko, J. Wang, M.S. Kallos and I.D. Gates

1007> A Novel Model of Foam Flooding Considering Multi-Factors for Enhancing Oil Recovery

Un nouveau modèle d'injection de mousse considérant de multiples facteurs afin d'améliorer la récupération de pétrole

J. Wang, H. Liu, H. Zhang, G. Zhang, P. Liu and K. Sepehrnoori
1025> Testing of Snorre Field Foam Assisted Water Alternating Gas (FAWAG) Performance in New Foam Screening Model

Vérification des performances de la méthode FAWAG (Foam Assisted Water Alternating Gas) sur le champ de Snorre, en Norvège, avec un nouveau modèle de sélection des mousses

P. Spirov and S. Rudyk

\section{ASPHALTENES}

1035> Structural Study of Asphaltenes from Iranian Heavy Crude Oil Étude structurale d'asphaltènes de pétrole brut lourd iranien L. Davarpanah, F. Vahabzadeh and A. Dermanaki

$1051>$ Experimental Study and Mathematical Modeling of Asphaltene Deposition Mechanism in Core Samples

Étude expérimentale et modélisation mathématique du mécanisme de déposition d'asphaltène dans des carottes de forage

T. Jafari Behbahani, C. Ghotbi, V. Taghikhani and A. Shahrabadi

1075> Prediction of the Gas Injection Effect on the Asphaltene Phase Envelope Prévision Prévision de l'effet d'injection de gaz sur l'enveloppe de phase des asphaltènes P. Bahrami, R. Kharrat, S. Mahdavi and H. Firoozinia

\section{HYDRATES}

1087> Methane Hydrate Formation and Dissociation in the Presence of Silica Sand and Bentonite Clay

Formation et dissociation d'hydrates de méthane en présence de sable de silice et d'argile de bentonite

V. Kumar Saw, G. Udayabhanu, A. Mandal and S. Laik

$1101>$ Prediction of Mass Flow Rate in Supersonic Natural Gas Processing Prédiction du débit massique dans les applications de traitement supersonique du gaz naturel

C. Wen, X. Cao, Y. Yang and Y. Feng

$1111>$ Experimental Study on Hydrate Induction Time of Gas-Saturated Water-in-Oil Emulsion using a High-Pressure Flow Loop

Étude expérimentale sur le temps d'induction d'hydrate d'une émulsion eau-enhuile saturée en gaz en utilisant une boucle à circulation sous haute pression X.F. Lv, B.H. Shi, Y. Wang, Y.X. Tang, L.Y. Wang and J. Gong

1125> Hollow Silica: A Novel Material for Methane Storage La silice creuse : un nouveau matériau pour le stockage de méthane V.D. Chari, P.S.R. Prasad and S.R. Murthy 


\title{
Prediction of the Gas Injection Effect on the Asphaltene Phase Envelope
}

\author{
Peyman Bahrami ${ }^{1 *}$, Riyaz Kharrat ${ }^{2}$, Sedigheh Mahdavi ${ }^{3}$ and Hamed Firoozinia ${ }^{4}$ \\ ${ }^{1}$ Department of Oil and Gas Engineering, Science and Research Branch, Islamic Azad University, Tehran - Iran \\ 2 Petroleum University of Technology, Tehran - Iran \\ ${ }^{3}$ Memorial University of Newfoundland - Canada \\ ${ }^{4}$ Research Institute of Petroleum Industry, Tehran - Iran \\ e-mail: pymnbahrami@yahoo.com - kharrat@put.ac.ir -s.mahdavi@mun.ca -firooziniah@ripi.ir \\ * Corresponding author
}

\begin{abstract}
Asphaltene instability may occur when pressure, temperature and compositional variations affect the reservoir oil. Permeability reduction, wettability alteration, and plugging of wells and flow lines are the consequences of this phenomenon. Therefore, it is crucial to investigate the asphaltene behavior in different thermodynamic conditions by knowing the Asphaltene Precipitation Envelope (APE) in a preventive way rather than the costly clean-up procedures. The selected reservoir oil has faced a remarkable decline in production due to several years of extraction, and Enhanced Oil Recovery (EOR) has been considered as a solution. Therefore, in this paper, a comprehensive study was carried out to predict the effects of different injected gases on asphaltene onset and to prevent future asphaltene precipitation based on the laboratory data. The Advanced Redlich-Kwong-Soave (RKSA) equation of state was considered to develop APE using Multiflash (Infochem Co.). For the selected reservoir oil, with temperature reduction at low temperatures, asphaltene precipitation weakened and made the onset pressure decrease, so this behavior is different from the results obtained in other published reports. On the basis of this model, several sensitivity analyses were performed with different gases (i.e., methane, $\mathrm{CO}_{2}, \mathrm{~N}_{2}$ and associated gases) to compare the risk of each gas for future EOR strategies. APE tend to expand as the amount of injected gases increases, except for $\mathrm{CO}_{2}$ gas injection, that showed another unconventional behavior for this crude oil. It was observed that for $\mathrm{CO}_{2}$ gas injection below a certain temperature, asphaltene stability increased, which can be considered as a good inhibitor of asphaltene precipitation.
\end{abstract}

Résumé - Prévision de l'effet d'injection de gaz sur l'enveloppe de phase des asphaltènes L'instabilité des asphaltènes peut se produire lorsque des variations de pression, de température et de composition affectent les réservoirs d'huile conduisant à une réduction de la perméabilité, à l'altération de la mouillabilité et au blocage de l'écoulement dans les puits et les conduites. Par conséquent, il est crucial d'étudier le comportement des asphaltènes pour différentes conditions thermodynamiques en connaissant leur domaine de précipitation (APE, Asphaltene Precipitation Envelope) de manière préventive pour limiter les opérations coûteuses de nettoyage. Le réservoir d'huile choisi pour cette étude a subi un déclin remarquable de sa production du fait de plusieurs années d'extraction et la récupération assistée (EOR, Enhanced Oil Recovery) a été considérée comme une solution prometteuse. Par conséquent, dans ce document, une étude détaillée basée sur des données de laboratoire est réalisée afin de prévoir 
les effets d'injection de différents gaz lors du début de la précipitation des asphaltènes et pour empêcher toute précipitation ultérieure. L'équation d'état avancée Redlich-Kwong-Soave (RKSA) a été considérée pour établir l'enveloppe APE en utilisant le logiciel Multiflash (Infochem Co.). Pour le réservoir de pétrole sélectionné, une réduction de la température diminua la précipitation d'asphaltènes et fit chuter la pression de départ. Ce comportement diffère des résultats précédemment publiés. De nombreuses analyses de sensibilité ont été réalisées pour différents gaz (méthane, $\mathrm{CO}_{2}, \mathrm{~N}_{2}$ et gaz associé) dans le but de comparer le taux de risque de chaque gaz pour différentes stratégies de récupération EOR. Les enveloppes APE ont tendance à croître lorsque la quantité de gaz injecté augmente, sauf pour de l'injection de $\mathrm{CO}_{2}$ qui a révélé un comportement non conventionnel avec ce pétrole brut. Il a été constaté qu'avec l'injection de $\mathrm{CO}_{2}$, en-dessous d'une certaine température, la stabilité des asphaltènes augmentait, ce qui peut être considéré comme un bon système d'inhibition de la précipitation des asphaltènes.

\section{INTRODUCTION}

Asphaltene deposition in near-wellbore formations, production tubing and surface facilities can occur upon pressure, temperature and composition variations. The latter may happen when reservoir oil blends with various gases during enhanced oil recovery $\left(\mathrm{CO}_{2}, \mathrm{~N}_{2}\right.$, dry and enriched gas injection), gas lift and acid stimulation. The effects of different gases on asphaltene stability have previously been studied in various fluids. Experimental investigation of asphaltene aggregation due to $\mathrm{N}_{2}$ injection showed asphaltene particles tend to precipitate as the amount of injected $\mathrm{N}_{2}$ increases (Jamaluddin et al., 2002), and other gases such as $\mathrm{CO}_{2}$, methane and propane could increase the asphaltene instability (Vafaie-Sefti et al., 2003). In addition to the fact that these parameters affect asphaltene stability, they could also change the Asphaltene Precipitation Envelope (APE). Observations showed that as the temperature increases, the onset pressure decreases (Andersen, 1994), whereas it might cause an increase at onset pressure in some cases (Gonzalez et al., 2012). Some authors reported that $\mathrm{CO}_{2}$ gas injection increases the Asphaltene Onset Pressure (AOP) at any temperature (Novosad and Costain, 1990; Srivastava and Huang, 1997; Takahashi et al., 2003; Vazquez and Mansoori, 2000), while other studies found that at some temperatures asphaltene particles could be more stable (Gonzalez et al., 2007). An oil production system can also experience a significant temperature change from the reservoir to the separator. This effect is even more significant in production of deep-sea reservoirs where seafloor temperatures are about $4{ }^{\circ} \mathrm{C}$. The consequences generally include changes in reservoir wettability, formation damage, downhole facility plugging and finally, affect the Enhanced Oil Recovery (EOR) project due to unfavorable economic consequences such as production delays and costly clean-up procedures (Akbarzadeh et al., 2007; Creek, 2005; Escobedo and Mansoori, 1997; Mansoori et al., 2007; Zekri et al., 2007).

The reservoir under study faced asphaltene deposition problems during early production of oil and the problem has become even more severe with further production. The producing interval is in the range of $2692-2725 \mathrm{~m}$ and the oil is transferred to an operation plant near the well site. After the first appearance of asphaltene deposition in surface facilities, a comprehensive study was performed in the laboratory to evaluate the AOP and contents of Saturates, Aromatics, Resins and Asphaltenes (SARA). In order to maintain the reservoir pressure and also prevent more asphaltene deposition and further problems in the future, it is necessary to investigate different strategies to predict asphaltene precipitation behavior. The amount of gas that can be dissolved in the oil before the asphaltene precipitation is an important parameter to consider in the design of the optimal gas injection scheme. The prediction of the phase behavior of asphaltene is essential in the design of well completion and/or surface facilities.

Although experimental determination of the full set of thermodynamic conditions in which asphaltenes begin to flocculate might be desirable for each specific crude oil, the cost of such a detailed characterization is prohibitive. An alternative is to obtain a minimum amount of laboratory data and incorporate that information into a thermodynamic model to predict the onset pressure over a wide range of conditions. To mimic experimental observations, current thermodynamic models generally require the use of many adjustable parameters, some of which cannot be verified experimentally (Leontaritis and Mansoori, 1987; Nghiem et al., 1993; Pan and Firoozabadi, 1998). 
One of the first effective models for asphaltene flocculation was a colloidal model that recognized asphaltene particles in crude oil as a colloid (Hirschberg et al., 1984). They treated the oil phase as a homogeneous liquid and modeled flocculation as a new phase of pure asphaltene. In some models, a solid phase was formed when flocculation occurred (Chung, 1992). Both approaches could result in a model that requires too many adjustable parameters and was very sensitive to small changes in parameter values. This means that the model must be refitted to a large quantity of experimental data for each fluid. Leontaritis and Mansoori (1987) proposed a thermodynamic colloidal model that is able to predict the onset of asphaltene flocculation. According to this model, asphaltene solid particles are stabilized by resin on their surface in a colloidal suspension system, and the state of crude oil and molecular weight of asphaltene can be determined by this model. Single-component solid model is one of the simplest models for asphaltene precipitation that was proposed by Nghiem et al. (1993), who used the model along with a flash calculation procedure for vapor/liquid/asphalt systems to predict asphaltene precipitation data under pressure depletion, gas or solvent injection conditions. They discovered that the model could not depict the true behavior of asphaltene precipitation with increasing solvent concentration under gas/solvent injection conditions. The micellization model of asphaltene precipitation is another model and it is assumed that one of the key factors in asphaltene deposition is micelle formation (Victorov and Firoozabadi, 1996). This model has shown good agreement with most experimentally observed results. However, this model could not predict asphaltene behavior under gas titration conditions. Later, another model was proposed to understand asphaltene precipitation with a detailed molecular-thermodynamic framework (Wu et al., 2000). This model considered strong interactions between asphaltene and resin molecules and between asphaltene molecules using the SAFT association theory, where asphaltene precipitation is treated as a liquid-liquid equilibrium with the oil. An effective model that describes solid deposition allows the engineer to carry out a variety of tasks from screening for potential problems through to examination of possible remediation strategies. In this work, the Multiflash commercial software was used for predicting the APE based on the RKSA Equation Of State (EOS). The purpose of this paper is to investigate the AOP for a live oil during pressure reduction, blending with different gases and to demonstrate the future strategies for the selected reservoir.

\section{CHARACTERIZATION METHODOLOGY}

Asphaltenes may destabilize, and precipitate out of the reservoir fluid when subjected to pressure, temperature
TABLE 1

Reservoir fluid characterization

\begin{tabular}{l|c}
\hline Reservoir temperature $\left({ }^{\circ} \mathrm{C}\right)$ & 96.1 \\
\hline Reservoir pressure (MPa) & 30.82 \\
\hline Bubble point pressure (MPa) & 9.87 \\
\hline Gas/oil ratio $\left(\mathrm{m}^{3} / \mathrm{m}^{3}\right)$ & 56.81 \\
\hline Oil API gravity (deg) & 20.32 \\
\hline Molecular weight of residual oil & 269 \\
\hline Molecular weight of reservoir oil & 169 \\
\hline SARA contents (ASTM D4124-97) & 24.8 \\
\hline Saturates (wt $\%)$ & 45.6 \\
\hline Aromatics (wt $\%)$ & 16.8 \\
\hline Resins (wt $\%)$ & 12.8 \\
\hline Asphaltenes (wt $\%)$ & \\
\hline
\end{tabular}

or compositional changes. It was used screening criteria to investigate the tendency of asphaltenes particles to precipitate. The crude oil under study was a $20.32^{\circ} \mathrm{API}$ fluid with the characteristics shown in Table 1 , and the total content of asphaltene was $12.8 \mathrm{wt} \%$.

The data required for the screening were PVT properties including the oil density at the bubble point pressure, the reservoir pressure, and the SARA contents of the Stock-Tank Oil (STO). Three plots are used for the screening; namely, the de Boer plot, the Asphaltene-Resin ratio and the ratio of Saturate/ Aromatic (S/A) to Asphaltene/Resin (A/R). The preliminary screening was conducted on the selected sample. The de Boer plot was developed based on field observations (de Boer et al., 1995), Figure 1 indicates that the reservoir fluid is in a moderate problem region. Moreover, the Asphaltene-Resin ratio screening method (Jamaluddin et al., 2001), suggests that the asphaltenes are unstable in the given fluid (Fig. 2). The last criterion demonstrated in Figure 3 also shows the reservoir fluid is in unstable zone (Stankiewicz et al., 2002). Thus, the results from the stability screening suggested that there may be potential for asphaltene problems in reservoir conditions. Hence, detailed measurements were conducted to determine the onset of asphaltene destabilization at various temperatures.

The reservoir fluid was flashed from reservoir conditions to ambient conditions to measure the Gas-Oil Ratio (GOR). Thus, it was anticipated that the STO would keep all the solids present in the reservoir fluid. 


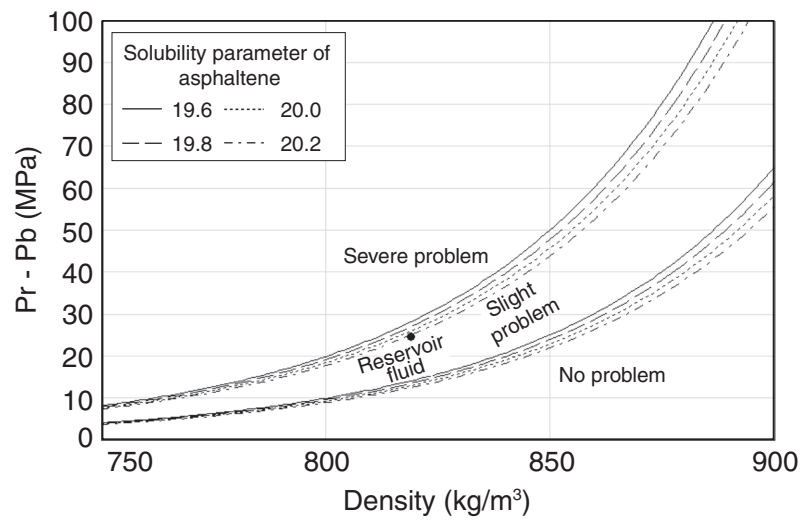

Figure 1

De Boer plot for reservoir sample.

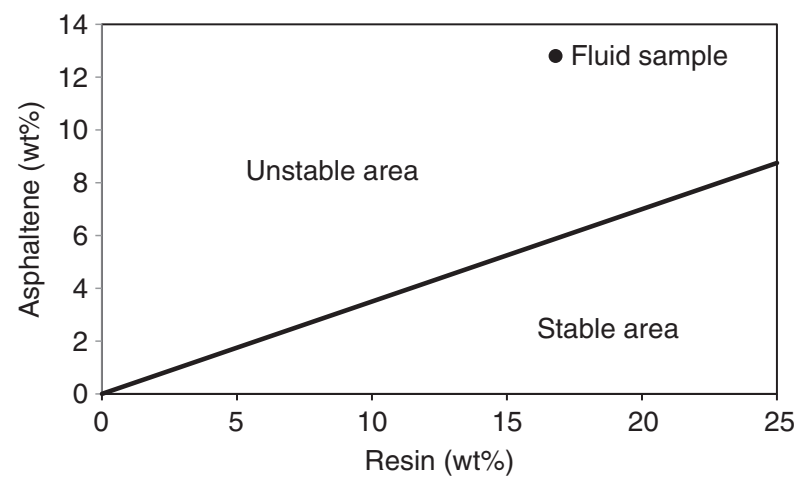

Figure 2

Asphaltene vs resin for reservoir sample.

TABLE 2

Reservoir fluid composition

\begin{tabular}{|c|c|c|c|c|c|c|c|c|}
\hline \multirow[t]{2}{*}{ Components } & \multirow{2}{*}{$\begin{array}{c}\text { MW } \\
(\mathrm{g} / \mathrm{mol})\end{array}$} & \multirow{2}{*}{$\begin{array}{l}\text { Density } \\
\left(\mathrm{g} / \mathrm{cm}^{3}\right)\end{array}$} & \multicolumn{2}{|c|}{ STO } & \multicolumn{2}{|c|}{ Flashed gas } & \multicolumn{2}{|c|}{ Monophasic fluid } \\
\hline & & & $(\mathrm{mol} \%)$ & $(w t \%)$ & $(\mathrm{mol} \%)$ & $(w t \%)$ & $(\mathrm{mol} \%)$ & $(w t \%)$ \\
\hline $\mathrm{N}_{2}$ & 28.04 & 0.809 & 0 & 0 & 0.91 & 0.792 & 0.39 & 0.065 \\
\hline $\mathrm{CO}_{2}$ & 44.01 & 0.817 & 0 & 0 & 4.10 & 5.603 & 1.74 & 0.458 \\
\hline $\mathrm{Cl}$ & 16.04 & 0.300 & 0 & 0 & 48.38 & 24.094 & 20.55 & 1.97 \\
\hline $\mathrm{C} 2$ & 30.07 & 0.356 & 0 & 0 & 17.22 & 16.078 & 7.31 & 1.314 \\
\hline $\mathrm{C} 3$ & 44.1 & 0.508 & 0.10 & 0.016 & 12.43 & 17.02 & 5.34 & 1.409 \\
\hline$i$-C4 & 58.12 & 0.567 & 0.13 & 0.029 & 2.17 & 3.917 & 1.00 & 0.347 \\
\hline$n$-C4 & 58.12 & 0.586 & 1.67 & 0.364 & 6.34 & 11.441 & 3.65 & 1.269 \\
\hline$i$-C5 & 72.15 & 0.625 & 3.85 & 1.041 & 2.10 & 4.704 & 3.10 & 1.337 \\
\hline$n$-C5 & 72.15 & 0.631 & 6.44 & 1.741 & 2.45 & 5.489 & 4.75 & 2.049 \\
\hline C6 & 84 & 0.690 & 7.73 & 2.432 & 2.44 & 6.364 & 5.48 & 2.753 \\
\hline $\mathrm{C} 7$ & 96 & 0.727 & 4.82 & 1.733 & 1.07 & 3.189 & 3.23 & 1.853 \\
\hline C8 & 107 & 0.749 & 2.03 & 0.813 & 0.36 & 1.197 & 1.32 & 0.844 \\
\hline C9 & 121 & 0.768 & 3.93 & 1.781 & 0.03 & 0.112 & 2.27 & 1.642 \\
\hline $\mathrm{C} 10$ & 134 & 0.782 & 3.80 & 1.907 & 0 & 0 & 2.19 & 1.754 \\
\hline $\mathrm{C} 11$ & 147 & 0.793 & 3.15 & 1.734 & 0 & 0 & 1.81 & 1.59 \\
\hline $\mathrm{C} 12+$ & 370 & 0.9769 & 62.35 & 86.409 & 0 & 0 & 35.87 & 79.346 \\
\hline Total & & & 100 & 100 & 100 & 100 & 100 & 100 \\
\hline
\end{tabular}

Also, the flashed gas and STO were used to measure their molecular composition using gas chromatography and microdistillation, respectively. These compositions were then recombined numerically to obtain the reservoir fluid composition using the measured GOR. In addition, the molecular weight and density of the STO were measured. After measuring the density and the molecular weight of the STO, these properties can be calculated for the plus fraction. The measured and calculated data for modeling purposes are presented in Table 2. It has 


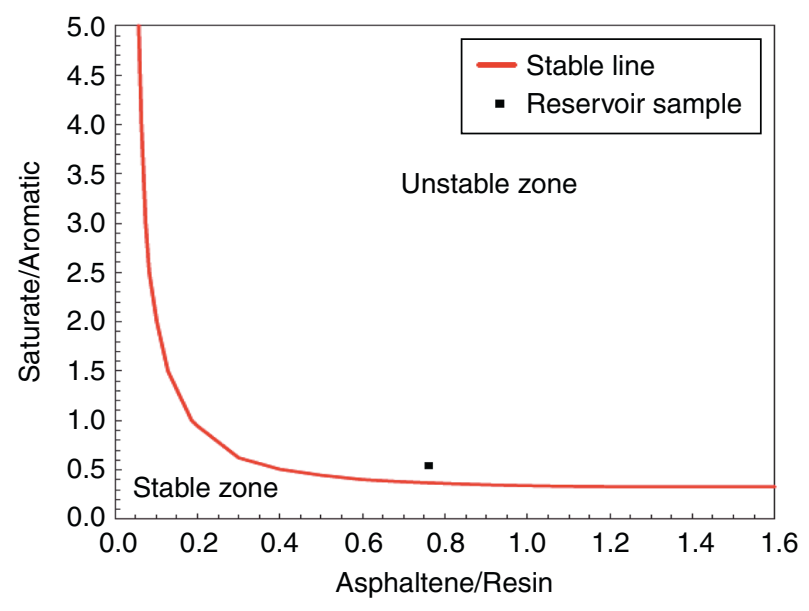

Figure 3

Saturate/Aromatic vs Asphaltene/Resin plot for reservoir sample.

been observed that the light components in the oil affect both the bubble pressure and AOP significantly (Gonzalez et al., 2005). Additionally, gas injection typically used for EOR purposes is generally rich in lighter hydrocarbons, and therefore the methodology proposed in the present work will enable good predictions for this type of injection.

\section{PRESSURE DEPLETION AND GAS INJECTION EXPERIMENTS}

A filtration method was used to measure the asphaltene content in natural depletion and gas injection tests. The reservoir fluid was transferred into the PVT cell to apply the desired pressure and temperature in contact with different ratios of gases. A 0.5 -micron metal filter made by the Swagelok company was used during the experiments. After the reservoir oil is stabilized in the PVT cell (in the pressure depletion scenario and/or in the gas injection scenario), the fluid passes through the filter during sampling at each stage. All asphaltene particles bigger than 0.5 microns do not pass through the filter, and the asphaltene content of the filtered fluid was determined by the IP-143 method (ASTM D6560-00, 2000). Finally, the differences between the asphaltene content of the original reservoir oil and the filtered samples can determine the amount of deposited asphaltene at each step. The asphaltene that this technique gives is physically extracted from oil, and by using some other techniques such as SARA analysis and molecular weight measurement, it can be further studied. The asphaltene onset points at different
TABLE 3

Upper onset points at different temperatures

\begin{tabular}{l|c|c|c}
\hline Temperature $\left({ }^{\circ} \mathrm{C}\right)$ & 96.1 & 80 & 60 \\
\hline Upper onset point $(\mathrm{MPa})$ & 32.34 & 34.96 & 31.36 \\
\hline
\end{tabular}

temperatures were achieved by extrapolation on asphaltene wt $\%$ versus the pressure plot by using the Peng-Robinson (PR) EOS (Nghiem et al., 1993; Nghiem and Coombe, 1997), and are summarized in Table 3. Figure 4 is an example of achieving the asphaltene onset pressure at $80^{\circ} \mathrm{C}$.

\section{MODELING OF ASPHALTENE PRECIPITATION}

In this work, the plus fraction splits into pseudocomponents with different ranges of molecular weight, and single carbon cuts can also be grouped into pseudocomponents (Whitson, 1983). The molecular weight and specific gravity of each component can be obtained by correlation (Riazi and Al-Sahhaf, 1996), and they are adjusted to match the measured values for the whole liquid sample. The mole fraction of each component is obtained by converting the weight fraction using the molecular weight. Then the mole fraction of the monophasic fluid can be calculated. The critical properties and acentric factors of each single carbon cut and pseudocomponents can be predicted by correlations (Kesler and Lee, 1976).

Here, the experimental results are used in the commercial software Multiflash to generate and estimate APE. The models that have been proposed in the past half century have some limitations. Poor prediction of the liquid phase density, lack of asphaltene-asphaltene and asphaltene-resin interactions, and a comprehensive correlation for vapor pressure of polar compounds are some common problems in these models (Edmonds et al., 1999a, 1999b).

The RKSA EOS is able to predict the properties of non-polar molecules in the vapor phase, and it is given by Equation (1) (Soave, 1972):

$$
\begin{gathered}
P=\frac{N R T}{V-b}+\frac{a}{V(V+b)} \\
a=\sum_{i j} \sqrt{a_{i} a_{j}}\left(1-K_{i j}\right) n_{i} n_{j} \\
b=\sum_{i} b_{i} n_{i} \\
a_{i}=a_{c i}\left(1+\kappa_{i}\left(1-\sqrt{T / T_{c i}}\right)\right)^{2}
\end{gathered}
$$




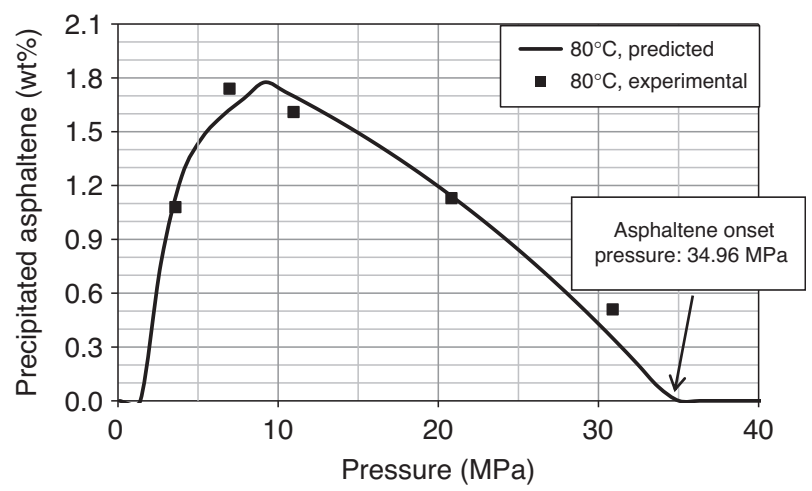

Figure 4

Precipitated asphaltene $\mathrm{wt} \%$ in natural depletion at $80^{\circ} \mathrm{C}$.

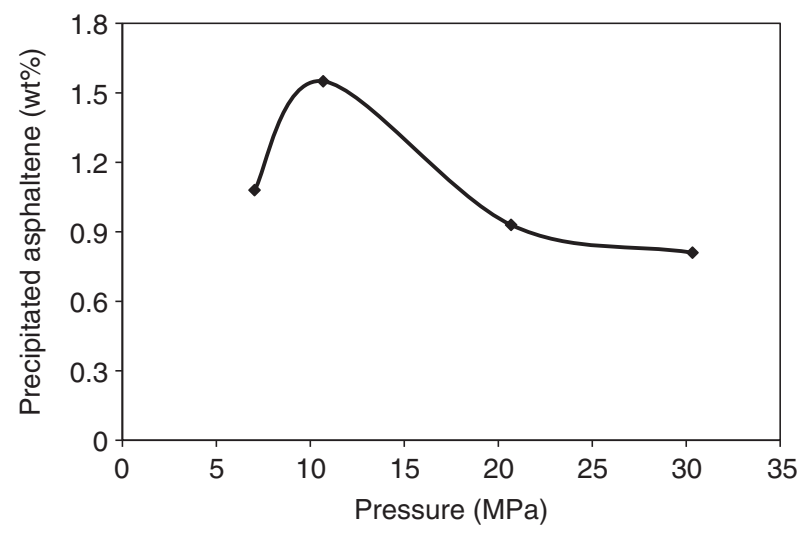

Figure 5

Experimental amount of asphaltene precipitation for reservoir oil at the reservoir temperature during a natural depletion test.

$$
\begin{gathered}
a_{c i}=0.42748 \frac{R^{2} T_{c i}^{2}}{P_{c i}} \\
\kappa_{i}=c_{0}+c_{1} \omega_{i}-c_{2} \omega_{i}^{2} \\
b_{i}=0.08664 \frac{R T_{c i}}{P_{c i}}
\end{gathered}
$$

where $n_{i, j}$ are the molar fractions of components, $\omega$ is the acentric factor, $P_{c i}$ and $T_{c i}$ are the critical pressure and temperature, $R$ is the gas constant, and $K_{i j}$ is the binary interaction between components $i$ and $j$. Equation (6) is a correlation for vapor pressure and $c_{0}, c_{1}$ and $c_{2}$ were determined based on vapor pressure data. Poor prediction of vapor pressure correlation at low temperatures, large errors in calculating liquid density and large density deviation at the critical point are some problematic issues in this model.

Pedrosa et al. (2013) applied some modifications to the EOS and presented the RKSA EOS to eliminate these issues. For an improved phase behavior prediction, $K_{i j}$ coefficients are fitted to vapor pressure data from the triple point to the critical point for each component. Furthermore, for a better prediction of liquid volume and density, Equation (8) is used (Peneloux et al., 1982).

$$
V=V^{\mathrm{RKS}}-\sum c_{i} n_{i}
$$

where $c_{i}$ is the temperature-dependent volume shift parameter, and it is fitted to the experimental saturation liquid density. The association and solvation of asphaltene molecules are described by the RKSA cubic EOS. In this model, asphaltene-asphaltene and asphaltene-resin interaction coefficients $\left(K_{\mathrm{AA}}\right.$ and $K_{\mathrm{AR}}$ ), the temperature-dependent association constants, are used to characterize the interactions between asphaltenes and asphaltene-resin particles (Zhang et al., 2012). This model is a computationally efficient way of considering the complex compounds and it is appropriate for engineering studies.

\section{RESULTS AND DISCUSSIONS}

\subsection{Effect of Pressure and Temperature}

The asphaltene phase behavior during a natural depletion test at the reservoir temperature is demonstrated in Figure 5, based on the filtration method (Nakhli et al., 2011). Figure 6 also shows the experimental oil density and calculated solubility parameter at different pressures. In this figure, the solubility is calculated based on the Asphaltene Instability Trend (ASIST) (Wang et al., 2006). As the pressure drops from the reservoir pressure to the bubble point pressure, the density and solubility parameters of the oil will decrease and it makes the asphaltene less stable. Further reduction in pressure below the bubble point pressure causes the solution gas to evolve from the liquid and as a result, the oil becomes richer in heavy-end components. Therefore, the density and solubility parameters of the oil increase and again the oil becomes a better solvent for precipitated asphaltene. The calculated solubility parameter of the oil supports this speculation. The minimum amount of solubility and oil phase density occurs at the bubble 


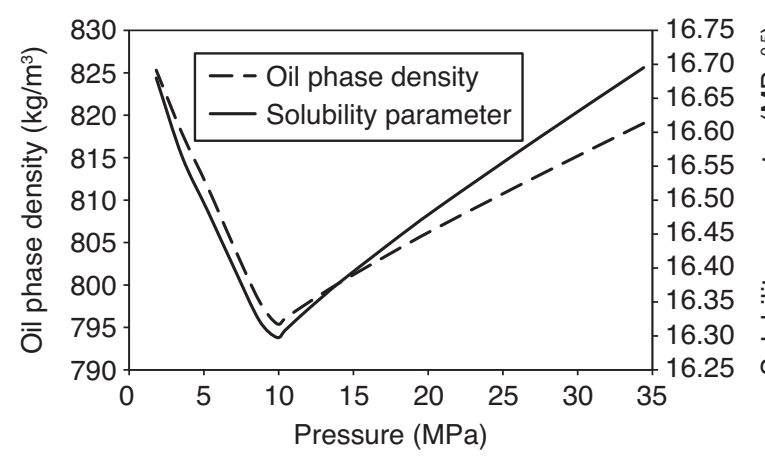

Figure 6

Calculated oil phase density and solubility parameters during a natural depletion test at the reservoir temperature.

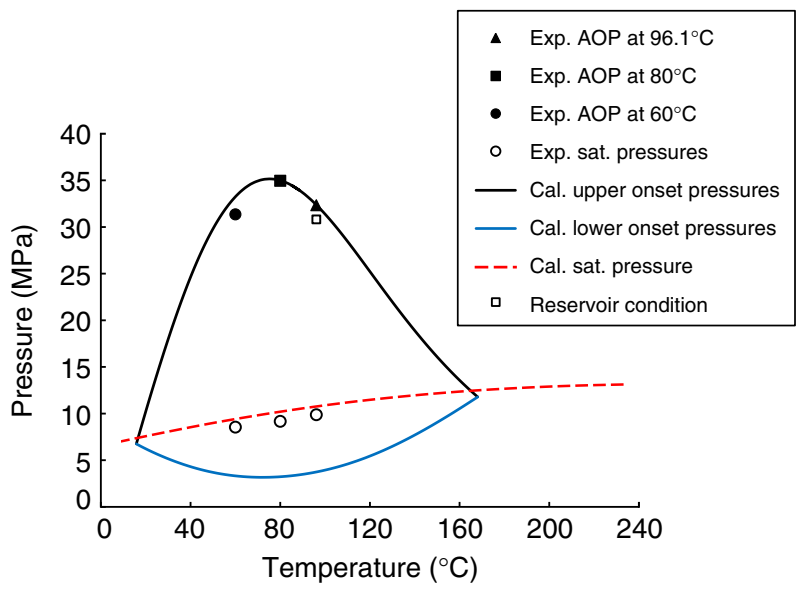

Figure 7

Asphaltene precipitation envelope for reservoir sample. point pressure where the asphaltene precipitation reaches its maximum.

When the pressure of the reservoir fluid drops at a specified temperature, the asphaltene is in the liquid phase region as the pressure is higher than the upper onset point of precipitation and there is no appearance of asphaltene flocculation. Asphaltene instability occurs when the pressure is between the upper onset and bubble point and between the bubble point and lower onset. The fluid is in oilasphaltene two-phase and gas-oil-asphaltene three-phase equilibrium respectively. As the reservoir fluid depressurizes below the lower onset point, the asphaltene particles redissolve completely in the liquid phase and the fluid is in the gas-oil two-phase region (Panuganti et al., 2012). Figure 7 presents the APE for the reservoir fluid with the plots of the bubble point and upper and lower onset pressures as a function of temperature and as can be clearly seen, there is good agreement between the calculated and experimental results. The oil is originally unstable, probably due to its initial high content of light components, which has a strong effect on asphaltene stability.

Asphaltenes are polar compounds which are stabilized in crude oil by the presence of resins. When the oil is diluted by light hydrocarbons, the concentration of resins decreases and a point may be reached where the asphaltenes are no longer stabilized. At this point, the asphaltene particles start to grow in size, and finally they flocculate and form a deposit. Since resins, as asphaltene stabilizers, work through the mechanism of polar interactions, their effect becomes weaker as the temperature rises, i.e. flocculation will occur as the temperature increases. Also, a decrease in the density of the fluid is another reason for asphaltene precipitation.
However, at a specified temperature, the solution entropy increases and the asphaltene melts and redissolves in the oil as the temperature increases. It causes a counterbalancing effect, and make the asphaltene precipitation either stronger or weaker when the temperature increases (Ting, 2003); while in other work, it was proposed that an increase in temperature will redissolve asphaltene particles (Hassanvand et al., 2012; Verdier et al., 2006). When the temperature is below $73.9^{\circ} \mathrm{C}$, the density of the oil decreases and causes asphaltene particles to flocculate as the temperature increases, and above this temperature the redissolution phenomenon is stronger. According to Figure 7, the temperature plays a more significant role in the upper onset pressure than lower onset pressure. At higher pressures the fluid nonideality is stronger than at lower pressures, and nonideality relates to interaction between molecules. At high pressures, molecules have lower mobility, but an increase in temperature changes the mobility significantly. However, at low pressure the non-ideality is weak and the fluid mobility is higher, therefore temperature plays a less important role. That is why at higher pressures and temperatures the change in the upper onset is greater than in the lower onset.

\subsection{Effect of Gas Injection}

Based on the model in the natural depletion test, the effect of different light gases was observed on the onset of the asphaltene precipitation. The possibility of asphaltene flocculation increases when light gases are exposed to the oil during miscible gas flooding processes. 

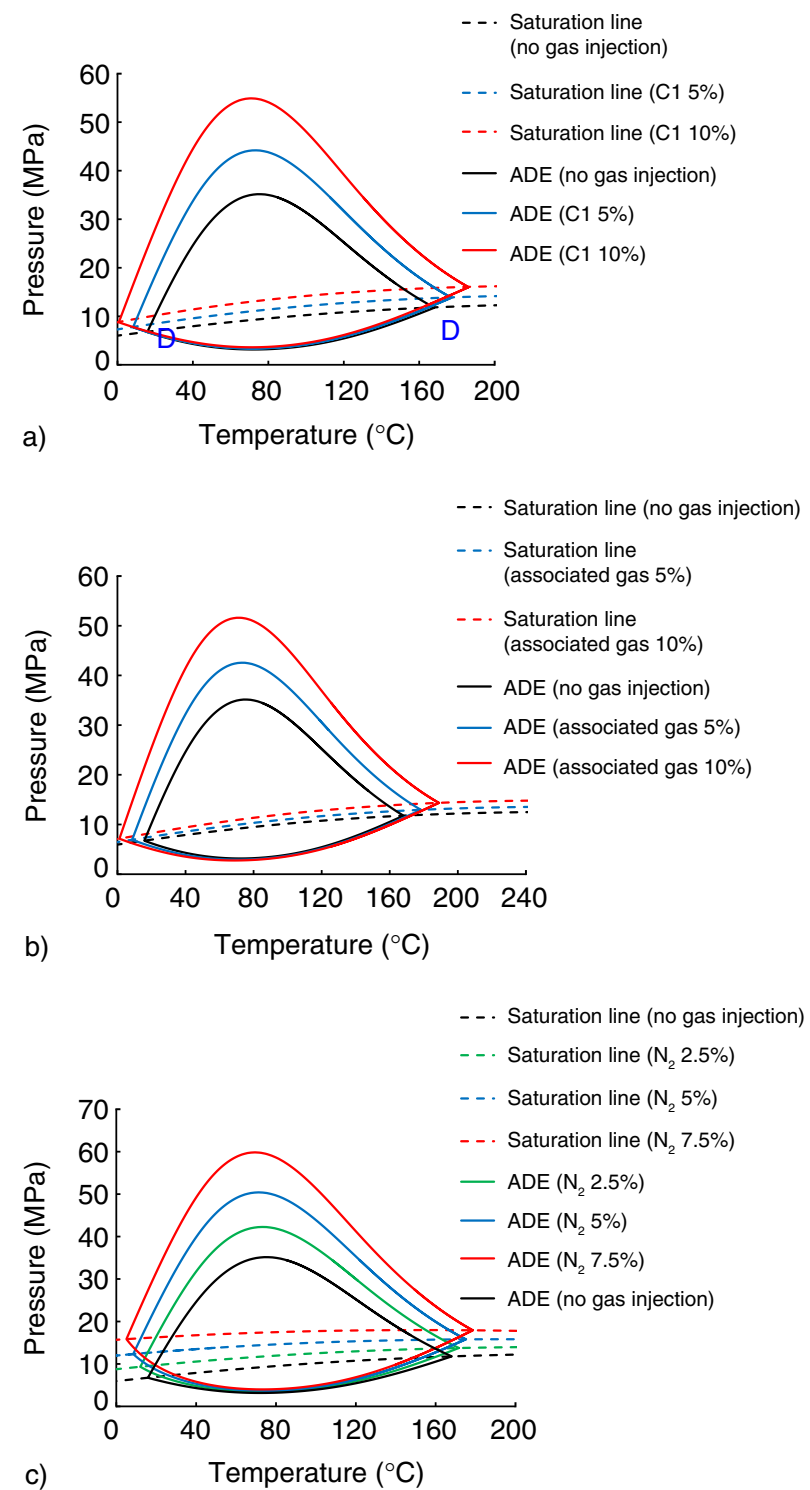

c) Temperature $\left({ }^{\circ} \mathrm{C}\right)$

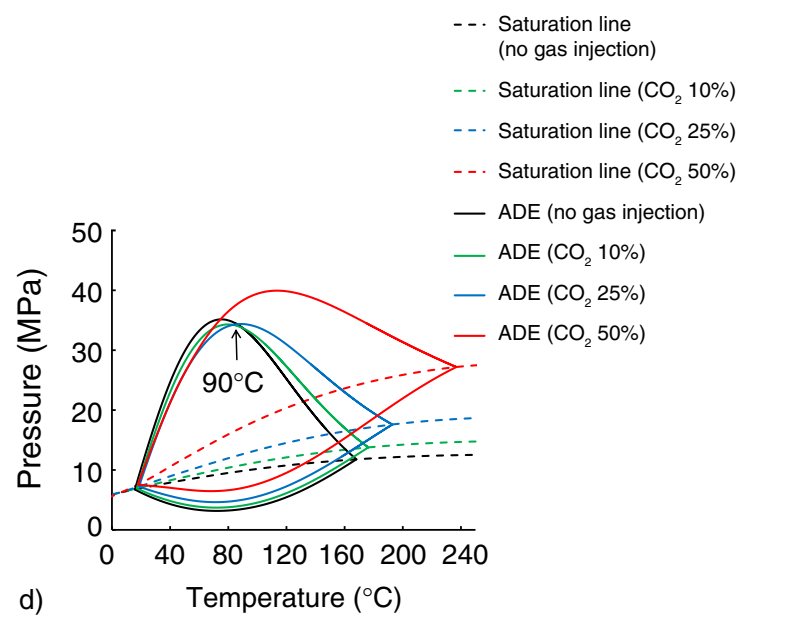

Figure 8

Effect of a) methane, b) associated gas, c) $\mathrm{N}_{2}$, d) $\mathrm{CO}_{2}$ on the APE.
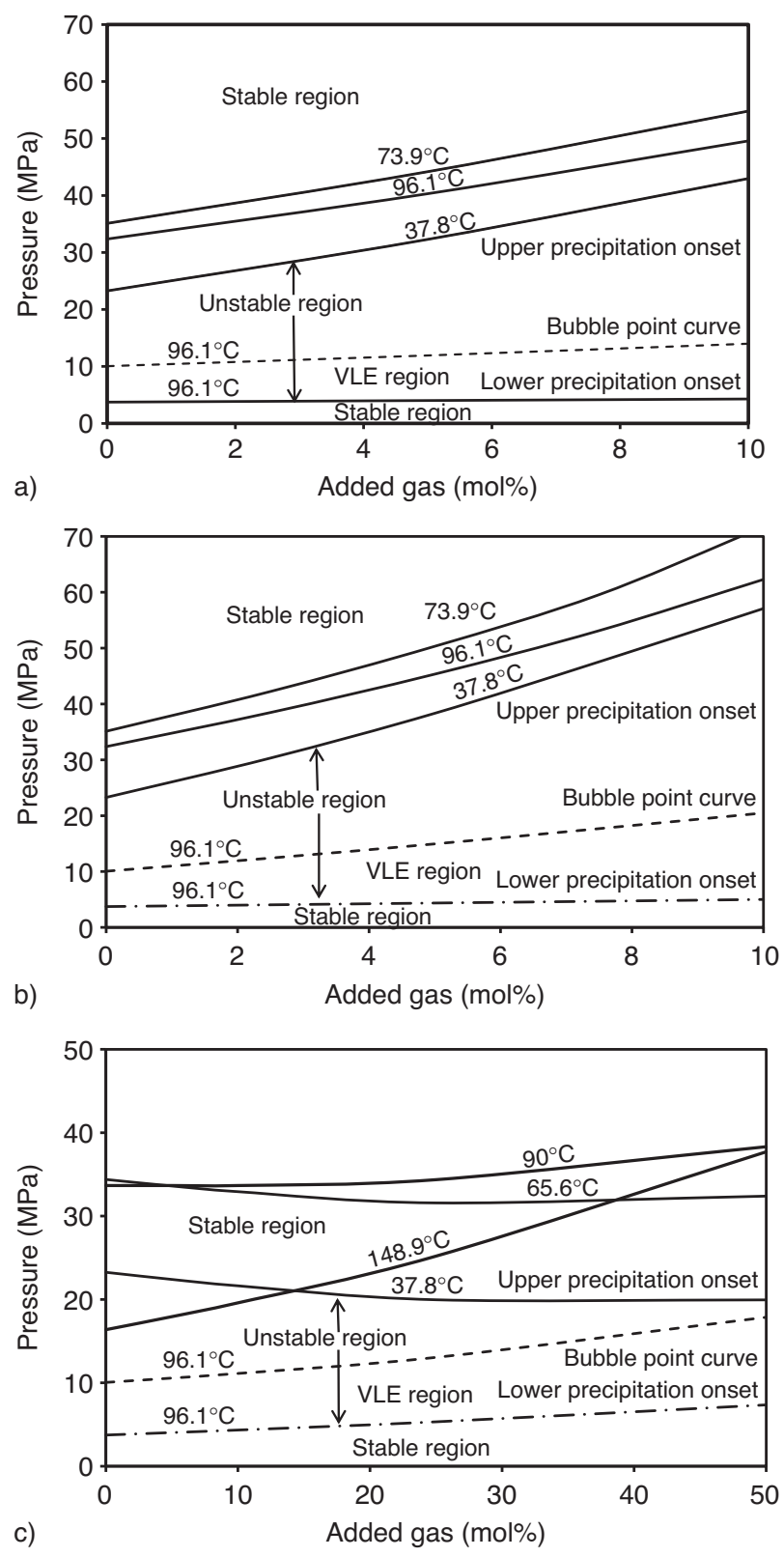

Figure 9

Temperature effect on asphaltene precipitation onset after the addition of a) methane, b) $\mathrm{N}_{2}$, c) $\mathrm{CO}_{2}$.

The bubble point curves and the asphaltene stability boundary increase when different compositions of methane, associated gas and $\mathrm{N}_{2}$ are added to the original fluid, as shown in Figures 8a to 8c. A different behavior is observed upon the addition of $\mathrm{CO}_{2}$. As shown in Figure 8d, for a known amount of injected $\mathrm{CO}_{2}$, below a specific crossover temperature, the stability of asphaltene improves (e.g., at $10 \mathrm{~mol} \%$ of injected gas, the crossover temperature is about $90^{\circ} \mathrm{C}$ ). 
TABLE 4

Summary of composition for original fluid and mixtures

\begin{tabular}{|c|c|c|c|c|c|}
\hline \multirow[b]{2}{*}{ Injected gas added $(\mathrm{mol} \%)$} & \multirow{2}{*}{$\frac{\text { Reservoir fluid }}{0}$} & \multicolumn{3}{|c|}{ Mixture of reservoir fluid and associated gas } & \multirow{2}{*}{$\frac{\text { Injected gas }}{100}$} \\
\hline & & 10 & 25 & 50 & \\
\hline \multicolumn{6}{|l|}{ Component $(\mathrm{mol} \%)$} \\
\hline $\mathrm{N}_{2}$ & 0.39 & 0.442 & 0.520 & 0.650 & 0.91 \\
\hline $\mathrm{CO}_{2}$ & 1.74 & 1.976 & 2.330 & 2.920 & 4.10 \\
\hline $\mathrm{C} 1$ & 20.55 & 23.333 & 27.508 & 34.465 & 48.38 \\
\hline $\mathrm{C} 2$ & 7.31 & 8.301 & 9.787 & 12.265 & 17.22 \\
\hline $\mathrm{C} 3$ & 5.34 & 6.049 & 7.113 & 8.885 & 12.43 \\
\hline$i-\mathrm{C} 4$ & 1.00 & 1.117 & 1.292 & 1.585 & 2.17 \\
\hline$n-\mathrm{C} 4$ & 3.65 & 3.919 & 4.323 & 4.995 & 6.34 \\
\hline$i-\mathrm{C} 5$ & 3.10 & 3.000 & 2.850 & 2.600 & 2.10 \\
\hline$n-\mathrm{C} 5$ & 4.75 & 4.520 & 4.175 & 3.600 & 2.45 \\
\hline C6 & 5.48 & 5.176 & 4.720 & 3.960 & 2.44 \\
\hline C7 & 3.23 & 3.014 & 2.690 & 2.150 & 1.07 \\
\hline $\mathrm{C} 8$ & 1.32 & 1.224 & 1.080 & 0.840 & 0.36 \\
\hline C9 & 2.27 & 2.046 & 1.710 & 1.150 & 0.03 \\
\hline $\mathrm{C} 10$ & 2.19 & 1.971 & 1.642 & 1.095 & 0 \\
\hline $\mathrm{C} 11$ & 1.81 & 1.629 & 1.358 & 0.905 & 0 \\
\hline $\mathrm{C} 12+$ & 35.87 & 32.283 & 26.902 & 17.935 & 0 \\
\hline Total & 100 & 100 & 100 & 100 & 100 \\
\hline
\end{tabular}

This behavior can be explained by the solubility parameter of $\mathrm{CO}_{2}$. At temperatures below the crossover point, the solubility parameter of reservoir oil is lower than the solubility parameter of $\mathrm{CO}_{2}$, so the probability of asphaltene precipitation in original oil is stronger than the $\mathrm{CO}_{2}$-induced asphaltene. This phenomenon is in agreement with the one that Gonzalez et al. (2007) proved based on the PC-SAFT model. Above the crossover temperature, the asphaltene solubility decreases and the onset pressure increases at higher temperatures. The increase in the amount of gas at different temperatures was also calculated, as shown in Figure 9. The onset pressure of the mixture increases at any temperature when methane, $\mathrm{N}_{2}$ and associated gases are added, which is why the upper onset curves in Figure 9 always have positive slopes. This behavior is completely different for $\mathrm{CO}_{2}$. At temperatures below the crossover point, the $\mathrm{CO}_{2}$ acts as an inhibitor and the upper onset curves have negative or zero slopes, whereas at temperatures above this point, it acts as a strong asphaltene precipitant and therefore the upper onset curves are ascending. The slope variation in the precipitation onset curves above and below the crossover point supports the specific behavior of the $\mathrm{CO}_{2}$.

This gas can behave as an inhibitor or precursor of asphaltene precipitation, depending upon the temperature of the system for a fixed pressure and live oil composition. This dual effect is not observed with other gases, such as $\mathrm{N}_{2}$ or methane, which always expand the ADE. Table 4 summarizes the fluid compositions at different mole percentages of associated gas based on the RKSA model.

Figure 10, that was calculated by Verdier in 2006, shows the solubility parameters of $\mathrm{N}_{2}$, methane and $\mathrm{CO}_{2}$ versus pressure, and among these gases $\mathrm{N}_{2}$ has the lowest solubility. In a wide range of temperatures, different amounts of $\mathrm{N}_{2}$ increase the upper onset pressures more than different percentages of methane and $\mathrm{CO}_{2}$; 


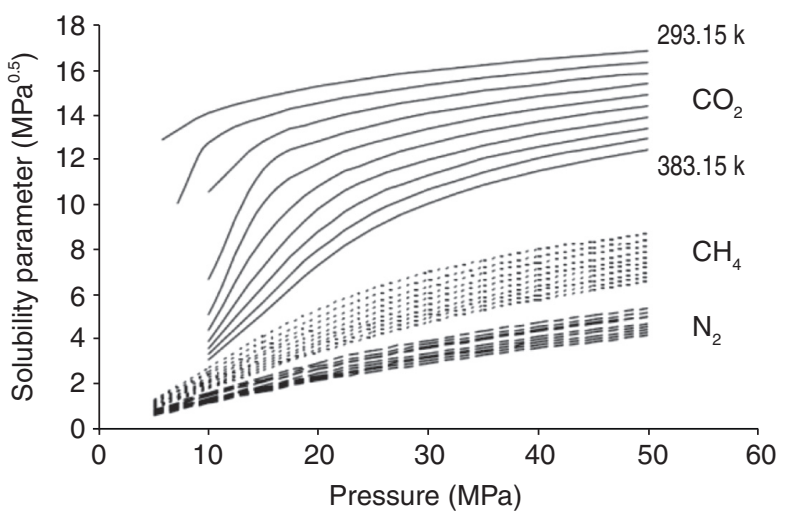

Figure 10

Solubility parameters of $\mathrm{N}_{2}$, methane and $\mathrm{CO}_{2}$ calculated every $10 \mathrm{~K}$, starting at $293.15 \mathrm{~K}$ for the top curves by Verdier (2006).

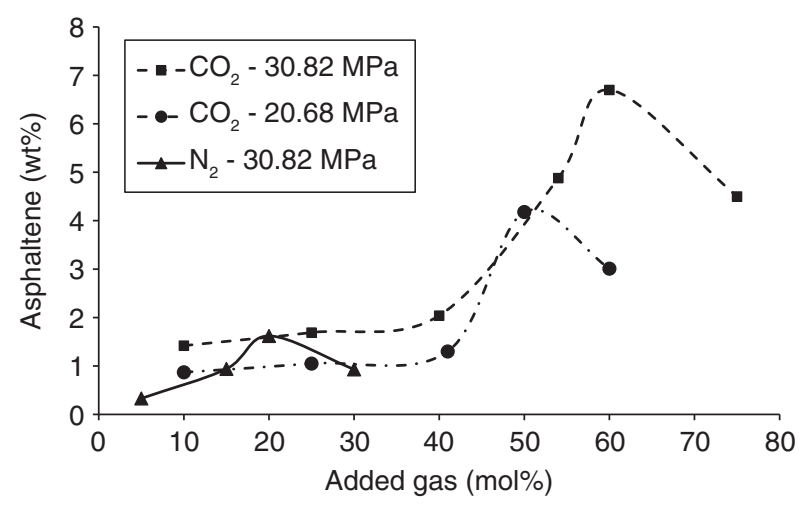

Figure 11

Experimental asphaltene precipitation due to $\mathrm{CO}_{2}$ and $\mathrm{N}_{2}$ gas injection at the reservoir temperature.

however, $\mathrm{CO}_{2}$ is a stronger precipitant agent at a specified temperature and leads to a higher content of asphaltene to precipitate.

Figure 11 proves this behavior of $\mathrm{CO}_{2}$ and $\mathrm{N}_{2}$ based on experimental results. $\mathrm{CO}_{2}$ and $\mathrm{N}_{2}$ gas injection tests were carried out at different mole percentages. By adding more gas into the system, the saturation pressure of the mixture increases. Therefore, at each pressure point, the asphaltene precipitation will increase, as the saturation pressure is below the test pressure. This means that before the mixture reaches the saturation pressure, all injected gases mix with the oil and the density of the mixture decreases. Based on the solubility theory the asphaltene precipitation increases when density decreases. When the operating pressure is lower than the saturation pressure, the gas does not mix with the fluid, and some light components of the oil can travel to the mixture.

The result of this phenomenon is asphaltene dissolution and an increase in the density of the oil. For a specified amount of gas injection, $\mathrm{N}_{2}$ increases the saturation pressure more than $\mathrm{CO}_{2}$, and it reaches its maximum content at lower percentages of injected gas compared with $\mathrm{CO}_{2}$. It is worth mentioning that if the results obtained here are confirmed by other authors, they need to be verified.

\section{CONCLUSION}

The general results are summarized as follows:

1. Depending on a counterbalancing effect of density and solution entropy, the temperature can cause an increase or a decrease in the amount of asphaltene precipitation;

2. Although temperature has a slight effect on the lower onset of asphaltene precipitation and the bubble point, the temperature can lead to a big change in the upper onset of asphaltene precipitation;

3. APE were gradually shifted to the high-pressure side and expanded as $\mathrm{C} 1, \mathrm{~N}_{2}$ and associated gas content increased. This phenomenon is stronger for $\mathrm{N}_{2}$;

4. The shape of APE are similar to the original reservoir oil APE;

5. $\mathrm{CO}_{2}$ injection causes asphaltene precipitation to increase at high temperatures but below a certain crossover, the asphaltene stability increases. Therefore, $\mathrm{CO}_{2}$ can behave as an inhibitor or precursor of asphaltene precipitation;

6. The APE was gradually expanded to a wide range of pressures and temperatures in a $\mathrm{CO}_{2}$ injection scenario, while the increase in the onset pressure was more significant in other gas injections;

7. Although at the same $\mathrm{mol} \%$ of $\mathrm{N}_{2}$ and $\mathrm{CO}_{2}$ injection, the APE expands more with $\mathrm{N}_{2}$ injection; $\mathrm{CO}_{2}$ is a strong precipitant agent at a specified temperature, which leads to a higher content of asphaltene to precipitate.

\section{REFERENCES}

ASTM D6560-00, (2000) Standard Test Method for Determination of Asphaltenes (Heptane Insolubles) in Crude Petroleum and Petroleum Products, London, UK.

Akbarzadeh K., Hammami A., Kharrat A., Zhang A. (2007) Asphaltenes-Problematic but Rich in Potential, Oilfield Review 19, 2, 22-43.

Andersen S.I. (1994) Effect of Precipitation Temperature on the Composition of $n$-Heptane Asphaltenes, Petroleum Science and Technology 12, 1, 51-74. 
Chung T.H. (1992) Thermodynamic Modeling for Organic Solid Precipitation, SPE Annual Technical Conference and Exhibition, 4-7 Oct, Washington, DC.

Creek J.L. (2005) Freedom of Action in the State of Asphaltenes: Escape from Conventional Wisdom, Energy \& Fuels 19, 4, 1212-1224.

de Boer R.B., Leerlooyer K., Eigner M.R.P., van Bergen A.R.D. (1995) Screening of Crude Oils for Asphalt Precipitation: Theory Practice, and the Selection of Inhibitors, SPE Production \& Facilities 10, 1, 55-61.

Edmonds B., Moorwood R.A.S., Szczepanski R., Zhang X., Heyward M., Hurle R. (1999a) A New Method to Give Quantitative Prediction of Asphaltene Deposition from Petroleum Fluids, Third International Symposium on Colloid Chemistry in Oil Production. Asphaltene \& Wax Deposition, ISCOP'99, Huatelco, Mexico, 14-17 Nov.

Edmonds B., Moorwood R.A.S., Szczepanski R., Zhang X. (1999b) Latest Developments in Integrated Prediction Modelling Hydrates, Waxes and Asphaltenes, Presented at $I B C$ Forum Controlling Hydrates, Waxes and Asphaltenes, Aberdeen, UK, 28-29 Oct.

Escobedo J., Mansoori G.A. (1997) Viscometric Principles of Onsets of Colloidal Asphaltene Flocculation in Paraffinic Oils and Asphaltene Micellization in Aromatics, SPE Production \& Facilities 12, 2, 116-122.

Gonzalez D.L., Ting P.D., Hirasaki G.J., Chapman W.G. (2005) Prediction of Asphaltene Instability under Gas Injection with the PC-SAFT Equation of State, Energy \& Fuels 19, 4, 1230-1234

Gonzalez D.L., Vargas F.M., Hirasaki G.J., Chapman W.G. (2007) Modeling Study of $\mathrm{CO}_{2}$-Induced Asphaltene Precipitation, Energy \& Fuels 22, 2, 757-762.

Gonzalez D.L., Garcia M.E., Diaz O. (2012) Unusual Asphaltene Phase Behavior of Fluids From Lake Maracaibo, Venezuela, SPE Latin America and Caribbean Petroleum Engineering Conference, Mexico City, Mexico, 16-18 April.

Hassanvand M., Shahsavani B., Anooshe A. (2012) Study of Temperature Effect on Asphaltene Precipitation by Visual and Quantitative Methods, Journal of Petroleum Technology and Alternative Fuels 3, 2, 8-18.

Hirschberg A., de Jong L.N.J., Schipper B.A., Meijer J.G. (1984) Influence of Temperature and Pressure on Asphaltene Flocculation, SPE Journal 24, 3, 283-293.

Jamaluddin A.K.M., Creek J., Kabir C.S., McFadden J.D., Cruz D., Joseph M.T., Joshi N., Ross B. (2001) A Comparison of Various Laboratory Techniques to Measure Thermodynamic Asphaltene Instability, SPE Asia Pacific Improved Oil Recovery Conference, Kuala Lumpur, Malaysia, 6-9 Oct.

Jamaluddin A.K.M., Jushi N., Iwere F., Gurpinar O. (2002) An Investigation of Asphaltene Instability Under Nitrogen Injection, SPE International Petroleum Conference and Exhibition, Villahermosa, Mexico, 10-12 Feb.

Kesler M.G., Lee B.I. (1976) Improve Prediction of Enthalpy of Fractions, Hydrocarbon Processing 53, 153-158.

Leontaritis K.J., Mansoori G.A. (1987) Asphaltene Flocculation During Oil Production and Processing: A Thermodynamic Collodial Model, SPE International Symposium on Oilfield Chemistry, San Antonio, Texas, 4-6 Feb.

Mansoori G.A., Vazquez D., Shariaty-Niassar M. (2007) Polydispersity of Heavy Organics in Crude Oils and Their Role in Oil Well Fouling, Journal of Petroleum Science and Engineering 58, 3-4, 375-390.
Nakhli H., Alizedeh A., Moqadam M.S., Afshari S., Kharrat R., Ghazanfari M.H. (2011) Monitoring of Asphaltene Precipitation: Experimental and Modeling Study, Journal of Petroleum Science and Engineering 78, 2, 384-395.

Nghiem L.X., Coombe D.A. (1997) Modeling Asphaltene Precipitation during Primary Depletion, SPE Journal 2, 2, 170-176.

Nghiem L.X., Hassam M.S., Nutakki R., George A.E.D. (1993) Efficient Modelling of Asphaltene Precipitation, SPE Annual Technical Conference and Exhibition, Houston, Texas, 3-6 Oct.

Novosad Z., Costain T.G. (1990) Experimental and Modeling Studies of Asphaltene Equilibria for a Reservoir Under $\mathrm{CO}_{2}$ Injection, SPE Annual Technical Conference and Exhibition, New Orleans, Louisiana, 23-26 Sept.

Pan H., Firoozabadi A. (1998) A Thermodynamic Micellization Model for Asphaltene Precipitation: Part I: Micellar Size and Growth, SPE Production \& Facilities 13, 2, 118-127.

Panuganti S.R., Vargas F.M., Gonzalez D.L., Kurup A.S., Chapman W.G. (2012) PC-SAFT Characterization of Crude Oils and Modeling of Asphaltene Phase Behavior, Fuel 93, 1, 658-669.

Pedrosa N., Szczepanski R., Zhang X. (2013) Integrated Equation of State Modelling for Flow Assurance, Fluid Phase Equilibria 359, 24-37.

Peneloux A., Rauzy E., Freze R. (1982) A Consistent Correction for Redlich-Kwong-Soave Volumes, Fluid Phase Equilibria 8, 1, 7-23.

Riazi M.R., Al-Sahhaf T.A. (1996) Physical Properties of Heavy Petroleum Fractions and Crude Oils, Fluid Phase Equilibria 117, 1-2, 217-224.

Soave G. (1972) Equilibrium Constants from a Modified Redlich-Kwong Equation of State, Chemical Engineering Science 27, 6, 1197-1203.

Srivastava R.K., Huang S.S. (1997) Asphaltene Deposition during $\mathrm{CO}_{2}$ Flooding: A Laboratory Assessment, SPE Production Operations Symposium, Oklahoma City, Oklahoma, 9-11 March.

Stankiewicz A.B., Flannery M.D., Fuex N.A., Bronze G., Couch J.L., Dubey S.T., Iyer S.D., Ratulowski J., Westerich J.T. (2002) Prediction of Asphaltene Deposition Risk in E\&P Operations, 3rd International Conference on Petroleum Phase Behavior and Fouling/AIChE Spring National Meeting, New Orleans, Louisiana, 10-14 March.

Takahashi S., Hayashi Y., Takahashi S., Yazawa N. (2003) Characteristics and Impact of Asphaltene Precipitation during $\mathrm{CO}_{2}$ Injection in Sandstone and Carbonate Cores: An Investigative Analysis Through Laboratory Tests and Compositional Simulation, SPE International Improved Oil Recovery Conference in Asia Pacific, Kuala Lumpur, Malaysia, 20-21 Oct.

Ting P.D. (2003) Thermodynamic Stability and Phase Behavior of Asphaltenes in Oil and of Other Highly Asymmetric Mixtures, PhD Thesis, Rice University.

Vafaie-Sefti M., Mousavi-Dehghani S.A., Mohammad-Zadeh M. (2003) A simple Model for Asphaltene Deposition in Petroleum Mixtures, Fluid Phase Equilibria 206, 1-2, 1-11.

Vazquez D., Mansoori G.A. (2000) Identification and Measurement of Petroleum Precipitates, Journal of Petroleum Science and Engineering 26, 1-4, 49-55.

Verdier S. (2006) Experimental Study and Modelling of Asphaltene Precipitation Caused by Gas Injection, PhD Thesis, Technical University of Denmark. 
Verdier S., Carrier H., Andersen S.I., Daridon J.L. (2006) Study of Pressure and Temperature Effects on Asphaltene Stability in Presence of $\mathrm{CO}_{2}$, Energy \& Fuels 20, 4, 1584-1590.

Victorov A.I., Firoozabadi A. (1996) Thermodynamic Micellizatin Model of Asphaltene Precipitation from Petroleum Fluids, AIChE Journal 42, 6, 1753-1764.

Wang J.X., Creek J.L., Buckley J.S. (2006) Screening for Potential Asphaltene Problems, SPE Annual Technical Conference and Exhibition, 24-27 Sept.

Whitson C.H. (1983) Characterizing Hydrocarbon Plus Fractions, Society of Petroleum Engineering Journal 23, 4, 683-694.

Wu J., Prausnitz J.M., Firoozabadi A. (2000) Molecular Thermodynamics of Asphaltene Precipitation in Reservoir Fluids, AIChE Journal 46, 1, 197-209.
Zhang X., Pedrosa N., Moorwood T. (2012) Modeling Asphaltene Phase Behavior: Comparison of Methods for Flow Assurance Studies, Energy \& Fuels 26, 2611-2620.

Zekri A.Y., Shedid S.A., Alkashef H. (2007) A New Technique for Treatment of Permeability Damage due to Asphaltene Deposition using Laser Technology, Journal of Petroleum Science and Engineering 59, 3-4, 300-308.

Manuscript submitted in January 2014 Manuscript accepted in August 2014 Published online in November 2014

Cite this article as: P. Bahrami, R. Kharrat, S. Mahdavi and H. Firoozinia (2014). Prediction of the Gas Injection Effect on the Asphaltene Phase Envelope, Oil Gas Sci. Technol 70, 6, 1075-1086. 